\title{
Meteorological Data near Rabbit Ears Pass, Colorado, U.S.A., 1984-2008
}

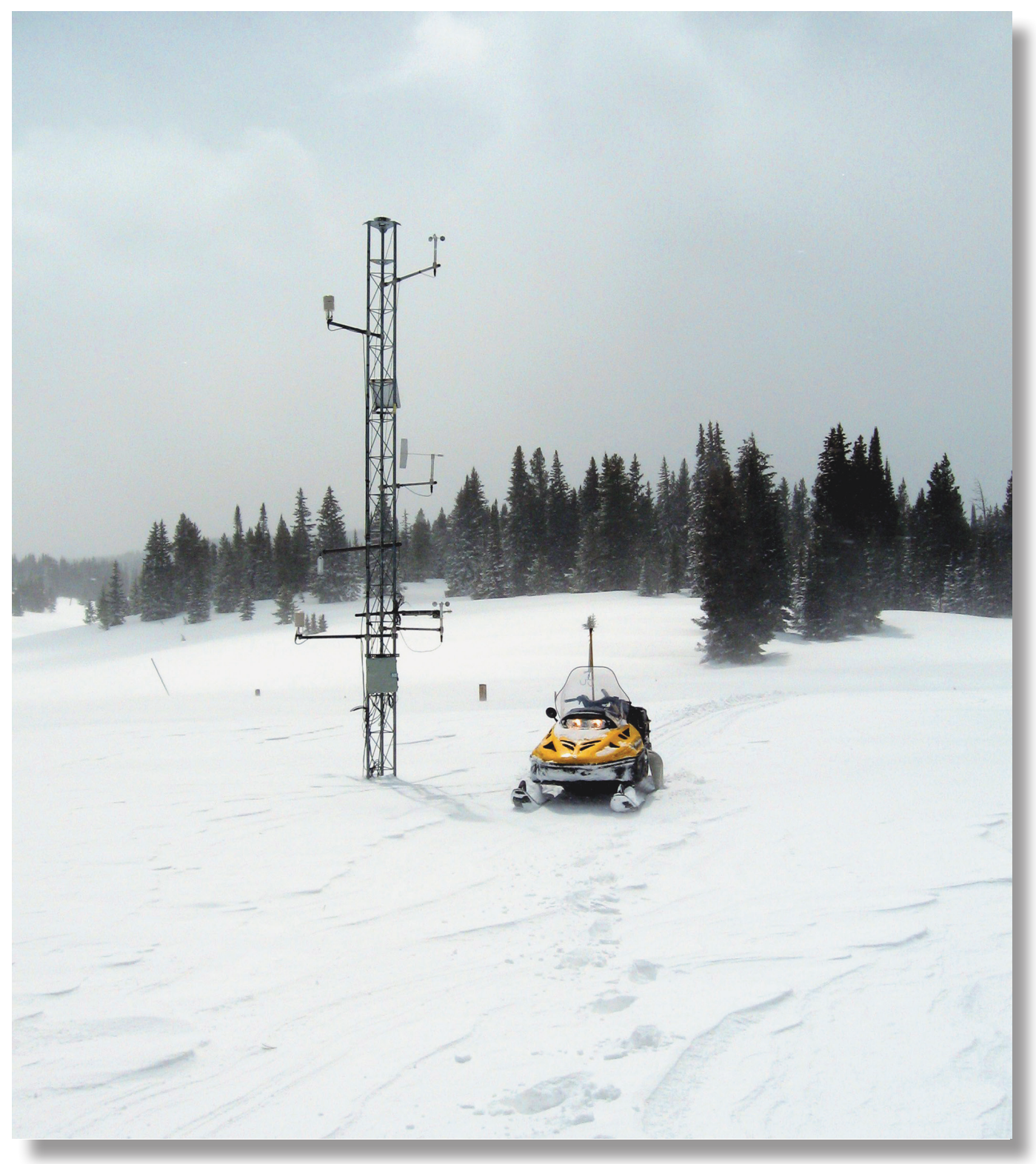

Data Series 415 
Cover photo: Meteorological tower near Rabbit Ears Pass, Colorado, April 11, 2007. (Photography by Douglas R. Halm, U.S. Geological Survey) 


\section{Meteorological Data near Rabbit Ears Pass, Colorado, U.S.A., 1984-2008}

By Douglas R. Halm, Larry D. Beaver, George H. Leavesley, and Michael M. Reddy

Data Series 415 


\title{
U.S. Department of the Interior \\ KEN SALAZAR, Secretary
}

\author{
U.S. Geological Survey \\ Suzette M. Kimball, Acting Director
}

U.S. Geological Survey, Reston, Virginia: 2009

For more information on the USGS - the Federal source for science about the Earth, its natural and living resources, natural hazards, and the environment, visit http://www.usgs.gov or call 1-888-ASK-USGS

For an overview of USGS information products, including maps, imagery, and publications, visit http://www.usgs.gov/pubprod

To order this and other USGS information products, visit http://store.usgs.gov

Any use of trade, product, or firm names is for descriptive purposes only and does not imply endorsement by the U.S. Government.

Although this report is in the public domain, permission must be secured from the individual copyright owners to reproduce any copyrighted materials contained within this report.

Suggested citation:

Halm, D.R., Beaver, L.D., Leavesley, G.H., and Reddy, M.M., 2009, Meteorological Data near Rabbit Ears Pass, Colorado, U.S.A., 1984-2008: U.S. Geological Survey Data Series 415, 2 p. 


\section{Contents}

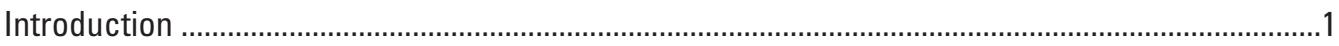

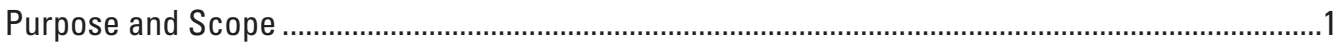

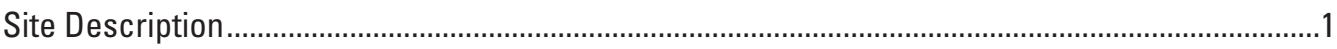

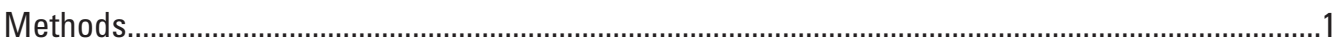

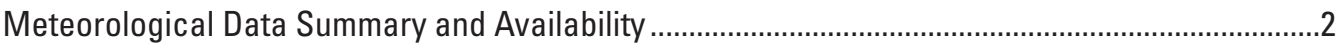

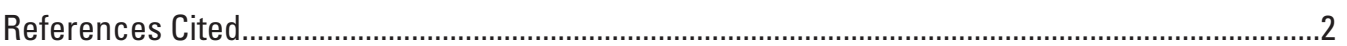

\section{Figure}

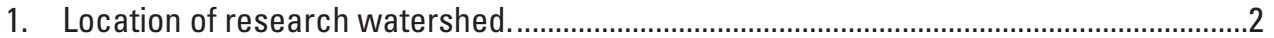

\section{Table}

1. Meterological data near Rabbit Ears Pass, Colorado,1984-2008......... See Excel file that accompanies report 


\section{Conversion Factors}

SI to Inch/Pound

\begin{tabular}{lcl}
\hline \multicolumn{1}{c}{ Multiply } & \multicolumn{1}{c}{ By } & To obtain \\
\hline centimeter $(\mathrm{cm})$ & 0.3937 & inch (in.) \\
millimeter $(\mathrm{mm})$ & 0.03937 & inch (in.) \\
meter $(\mathrm{m})$ & 3.281 & foot (ft) \\
kilometer $(\mathrm{km})$ & 0.6214 & mile (mi) \\
kilometer $(\mathrm{km})$ & 0.5400 & mile, nautical (nmi) \\
meter $(\mathrm{m})$ & 1.094 & yard (yd) \\
\hline & \multicolumn{1}{c}{ Area } & \\
\hline square meter $\left(\mathrm{m}^{2}\right)$ & 0.0002471 & acre \\
hectare (ha) & 2.471 & acre \\
square hectometer $\left(\mathrm{hm}^{2}\right)$ & 2.471 & acre \\
square kilometer $\left(\mathrm{km}^{2}\right)$ & 247.1 & acre \\
square centimeter $\left(\mathrm{cm}^{2}\right)$ & 0.001076 & square foot $\left(\mathrm{ft}^{2}\right)$ \\
square meter $\left(\mathrm{m}^{2}\right)$ & 10.76 & square foot $\left(\mathrm{ft}^{2}\right)$ \\
square centimeter $\left(\mathrm{cm}^{2}\right)$ & 0.1550 & square inch $\left(\mathrm{ft}^{2}\right)$ \\
square hectometer $\left(\mathrm{hm}^{2}\right)$ & 0.003861 & section $\left(640 \mathrm{acres}^{2}\right.$ or 1 square mile) \\
hectare (ha) & 0.003861 & square mile $\left(\mathrm{mi}^{2}\right)$ \\
square kilometer $\left(\mathrm{km}^{2}\right)$ & 0.3861 & square mile $\left(\mathrm{mi}^{2}\right)$ \\
& & \\
\hline
\end{tabular}

Temperature in degrees Celsius $\left({ }^{\circ} \mathrm{C}\right)$ may be converted to degrees Fahrenheit $\left({ }^{\circ} \mathrm{F}\right)$ as follows:

$$
{ }^{\circ} \mathrm{F}=\left(1.8 \times^{\circ} \mathrm{C}\right)+32
$$

Temperature in degrees Fahrenheit $\left({ }^{\circ} \mathrm{F}\right)$ may be converted to degrees Celsius $\left({ }^{\circ} \mathrm{C}\right)$ as follows:

$$
{ }^{\circ} \mathrm{C}=\left({ }^{\circ} \mathrm{F}-32\right) / 1.8
$$

Altitude, as used in this report, refers to distance above the vertical datum.

Vertical coordinate information is referenced to the North American Vertical Datum of 1988 (NAVD 88).

Horizontal coordinate information is referenced to the North American Datum of 1983 (NAD 83). 


\title{
Meteorological Data near Rabbit Ears Pass, Colorado, U.S.A., 1984-2008
}

\author{
By Douglas R. Halm, Larry D. Beaver, George H. Leavesley, and Michael M. Reddy
}

\section{Introduction}

In 1983, a snowmelt energy budget study was initiated by the U.S. Geological Survey on a small watershed near Rabbit Ears Pass, Colorado to better understand snowmelt processes. The study included data collection from hydrological and meteorological instrumentation. In 2007, the project was terminated, although air temperature and relative humidity $(\mathrm{RH})$ data collection are still active at the time of this report (2009). Interest in long term, high-altitude meteorological sites has increased recently due to the increased awareness of global climate change. The meteorological data collected near Rabbit Ears Pass may aid researchers involved in global climate change studies.

\section{Purpose and Scope}

The purpose of this report is to publish a long-term, highaltitude meteorological data set. Meteorological data for air temperature, RH, wind speed, and precipitation are presented for the years 1984-2008.

\section{Site Description}

The research watershed is located near Rabbit Ears Pass, about 18 kilometers $(\mathrm{km})$ southeast of Steamboat Springs, Colorado (fig. 1). The study area is the watershed of a tributary of Walton Creek and is approximately 200 hectares (ha) and ranges in altitude from 2,910-3,035 meters (m). The watershed is predominantly covered by soil with a few areas of exposed bedrock. It is about 30 percent forested with mostly coniferous forest and diffuse patches of Aspen (Peters and Leavesley, 1995). Average annual precipitation for the period 1971-2000 ranges from 1,270-1,400 millimeters (mm) per year (Oregon Climate Services, 2008).

\section{Methods}

Temperature, RH, and wind speed instruments were mounted on a $10-\mathrm{m}$ tower located in a large clearing (lat $40.3994^{\circ} \mathrm{N}$., long $106.6459^{\circ}$ W.) at 2,962 m (fig. 1). A precipitation gage was located in a clearing (lat $40.3945^{\circ} \mathrm{N}$., long $106.6488^{\circ} \mathrm{W}$.) approximately $600 \mathrm{~m}$ from the tower at $2,899 \mathrm{~m}$. Two temperature and $\mathrm{RH}$ sensors were mounted on the tower, one at $5 \mathrm{~m}$ and one at $2 \mathrm{~m}$ above the ground surface. The wind speed sensor was mounted on the tower at $2 \mathrm{~m}$. During snow cover, when snow depth increased or decreased, the sensors were moved to keep them approximately $2 \mathrm{~m}$ and $5 \mathrm{~m}$ above the snow surface.

Air temperature and $\mathrm{RH}$ were measured using three different instruments during the study period. The initial installation used two Campbell Scientific 201 thermistor/ RH sensors. The Campbell Scientific 201 sensor contained a Phys-Chemical Research model PCPC-11 RH sensor with an accuracy of $+/-3$ percent and a Fenwal UUT-51J1 thermistor with an accuracy of $+/-0.2^{\circ} \mathrm{C}$. On January 7 , 1985, the Campbell Scientific 201 sensors were replaced with Campbell Scientific 207 sensors, which are essentially the same as the Campbell Scientific 201 sensors but configured for the new line of Campbell Scientifics data loggers. On March 24, 1997, the Campbell Scientific 207 sensors were replaced with Campbell Scientific HMP35C temperature and RH sensors. The Campbell Scientific HMP35C sensor contained a thermistor for temperature with an accuracy of $+/-0.4{ }^{\circ} \mathrm{C}$, and a Vaisala capacitive polymer $\mathrm{H}$ chip for measuring $\mathrm{RH}$ with an accuracy of $+/-2$ percent. Wind speed was measured by a MetOne $014 \mathrm{~A}$ anemometer, with an accuracy of $+/-0.11$ meters per second $(\mathrm{m} / \mathrm{s})$ that was set and maintained at $2 \mathrm{~m}$ above ground or snow surface. Precipitation was measured using a Belfort Universal Recording Rain Gage 5-780 Series with an accuracy of $1 / 2$ of 1 percent, and sensitivity of $0.25 \mathrm{~mm}$.

All sensors were measured by Campbell Scientific CR21 or CR21X data loggers and the readings were stored on Campbell Scientific SM192 or SM716 storage modules. The stored data were either retrieved by a field computer at the site 

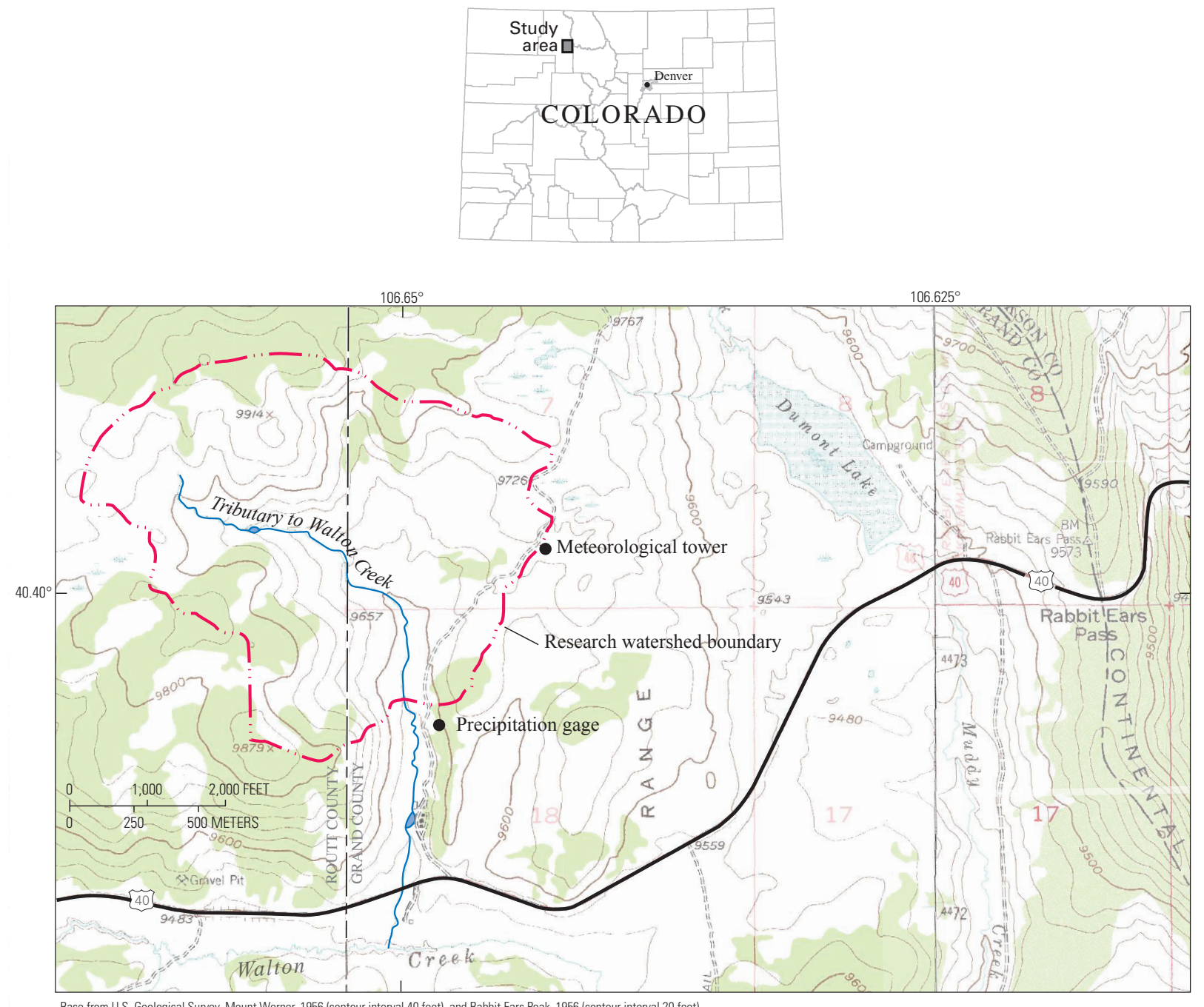

Base from U.S. Geological Survey, Mount Werner, 1956 (contour interval 40 feet), and Rabbit Ears Peak, 1956 (contour interval 20 feet).

Figure 1. Location of research watershed.

or the storage module was brought back to the office and the data retrieved by an office computer. The meteorological data were then visually inspected and plotted, and obvious outliers and bad data sections were removed.

\section{Meteorological Data Summary and Availability}

Temperature data presented in this report were collected from March 1, 1984, to February 20, 2008. RH data were collected from January 26, 1985, to February 20, 2008. Wind speed data were collected from February 17, 1984, to October 1, 2007. Precipitation data were collected from January 1, 1984, to October 1, 2007.

In table 1, temperature data are presented for 5-m and 2-m daily maximum, minimum, and mean values. $\mathrm{RH}$ data are presented for 5-m and 2-m daily maximum and minimum values. Wind speed data are presented for 2-m daily maximum and mean values. Precipitation data are presented as daily totals. Table 1 is an Excel spread sheet of the meteorological data and can be accessed at https//pubs.usgs.gov/ds/415.

\section{References Cited}

Peters, N.E., and Leavesley, G.H., 1995, Biotic and abiotic processes controlling water chemistry during snowmelt at Rabbit Ears Pass, Rocky Mountains, Colorado, USA: Water, Air and Soil Pollution, v. 79, no. 1-4, p. 171-190.

Oregon Climate Service, State annual precipitation maps, 2008, accessed July 3, 2008, at URL http://www.ocs.oregonstate.edu/index.html 
Publishing support provided by:

Denver Publishing Service Center

For more information concerning this publication, contact:

Chief, Branch of Regional Research, Central Region

Box 25046, Mail Stop 418

Denver, CO 80225

(303) 236-5021

Or visit the USGS National Research Program Web site at: http://water.usgs.gov/nrp/ 
